Pesq. Vet. Bras. 35(6):531-535, junho 2015 DOI: $10.1590 / \mathrm{S} 0100-736 \mathrm{X} 2015000600007$

\title{
Occurrence and risk factors assessment associated with Mycoplasma gallisepticum (MG) infection in chickens in the semiarid region of Pernambuco, Brazil ${ }^{1}$
}

\author{
Sílvio G. de Sá2 , José W. Pinheiro Júnior ${ }^{3}$, Sineide M. de Oliveira Vilela ${ }^{4}$, Erica P.B.X. Moraes $^{3 *}$, \\ Pedro P.F. Albuquerque ${ }^{2}$, Débora R.A. Ferreira ${ }^{2}$ and Rinaldo A. Mota ${ }^{2}$
}

\begin{abstract}
De Sá S.G., Pinheiro Junior J.W., Vilela S.M.O., Moraes E.P.B.X., Albuquerque P.P.F., Porto W.J.N., Ferreira D.R.A. \& Mota R.A. 2015. Occurrence and risk factors assessment associated with Mycoplasma gallisepticum (MG) infection in chickens in the semiarid region of Pernambuco, Brazil. Pesquisa Veterinária Brasileira 35(6):531535. Laboratório de Doenças Infecto-Contagiosas dos Animais Domésticos, Departamento de Medicina Veterinária, Universidade Federal Rural de Pernambuco, Rua Dom Manoel de Medeiros s/n, Dois Irmãos, Recife, PE 52171-900, Brazil. E-mail: ericaxmoraes@globo.com

The aim of the present study was to assess the occurrence of Mycoplasma gallisepticum (MG) infection and risk factors of this disease in three hundred serum samples from on 23 familiar agricultural properties in the semiarid region of the state of Pernambuco, Brazil. ELISA was used to study antibodies anti-Mycoplasma gallisepticum. The univariate analysis (chi-squared test or Fischer's exact test) followed by multivariate analysis (logistic regression) were used to assess the risk factors with two variables: management and sanity of the poultry. It was detected a frequence of $53.33 \%(157 / 300)$ of the birds were positive for MG, with $100 \%$ foci. The risk factors confirmed by multivariate analysis, in the present study, were the presence of other poultry species on the property, including Numida meleagris $(\mathrm{OR}=2.22 ; \mathrm{p}=0.005)$, parrots $(\mathrm{OR}=1.72 ; \mathrm{p}=0.027)$, and of passerines $(\mathrm{OR}=1.88 ; \mathrm{p}=0.007)$. These results showed that Mycoplasma gallisepticum infection is endemic among backyard poultry in the semiarid region of the state of Pernambuco. These birds could be a source of infection for other wild or domestic poultry. . This is the first report of the occurrence of avian mycoplasmosis in backyard poultry in the state of Pernambuco in northeastern Brazil. The risk factors identified should serve as a parameter for the health authorities to seek solutions related to controlling the disease.
\end{abstract}

INDEX TERMS: Avian mycoplasmosis, Mycoplasma gallisepticum, chickens, Gallus gallus domesticus, family poultry farming, risk factors.

RESUMO.- [Ocorrência e fatores de riscos associados à infecção por Mycoplasma gallisepticum em galinhas na região Semiárida do estado de Pernambuco.] Objetivo do presente estudo foi avaliar a ocorrência de infecção por

\footnotetext{
${ }^{1}$ Received on November 26, 2014.

Accepted for publication on June 15, 2015.

${ }^{2}$ Laboratório de Doenças Infecto-Contagiosas dos Animais Domésticos, Departamento de Medicina Veterinária, Universidade Federal Rural de Pernambuco (UFRPE), Rua Dom Manoel de Medeiros s/n, Dois Irmãos, Recife, PE 52171-900, Brazil.

${ }^{3}$ Unidade Acadêmica de Garanhuns, UFRPE, Av. Bom Pastor s/n, Boa Vista, Garanhuns, PE 55292-270, Brazil. *Corresponding author: ericaxmoraes@ globo.com

${ }^{4}$ Laboratório de Diagnóstico Animal (Lada), Rua Caratinga 62, sl. 1, Zumbi, Recife, PE 50720-490, Brazil.
}

Mycoplasma gallisepticum (MG) e os fatores de risco dessa doença em trezentas amostras de soro sanguíneo de galinhas domésticas em 23 propriedades da agricultura familiar na região semiárida do estado de Pernambuco, Brasil. Para a pesquisa de anticorpos contra Mycoplasma gallisepticum utilizou-se o Ensaio Imunoenzimático (ELISA). A análise univariada (Qui-quadrado ou Exato de Fischer) seguida pela análise multivariada (Regressão Logística) foram utilizadas para avaliar os fatores de risco com duas variáveis: manejo e sanidade das aves. Foi detectada uma frequência de 53,33\% (157/300) de aves soropositivas para MG com $100 \%$ de focos. Os fatores de risco confirmados na análise multivariada, neste estudo, foram a criação de outras espécies de aves na propriedade como Numida meleagris $(\mathrm{OR}=2,22 ; \mathrm{p}=0,005)$, criação de diferentes espécies de psi- 
tacídeos $(\mathrm{OR}=1,72 ; \mathrm{p}=0,027)$ e a criação de passeriformes $(\mathrm{OR}=1,88 ; \mathrm{p}=0,007)$. Estes resultados demonstram que a infecção por Mycoplasma gallisepticum é endêmica entre galinhas de criação doméstica na região semiárida do estado de Pernambuco. Estas aves podem atuar como fonte de infecção para outras aves silvestres e domésticas. Este é o primeiro relato da ocorrência de micoplasmose aviária em galinhas de criação doméstica no estado de Pernambuco, nordeste do Brasil. Os fatores de risco identificados devem servir como um parâmetro para as autoridades sanitárias buscarem soluções de controle da doença.

TERRMOS DE INDEXAÇÃO: Micoplasmose aviária, Mycoplasma gallisepticum, aves, Gallus gallus domesticus, avicultura familiar, fatores de risco.

\section{INTRODUCTION}

In recent decades, few sectors of the world economy have grown as much as the Brazilian poultry industry (Brazilian Poultry Association -Annual Report - UBABEF 2014). Advances in the areas of biotechnology related with the animal health, as well as the establishment of health barriers and official plans to control and prevent disease, have guaranteed a satisfactory performance of the activity in the country (Turra 2012). On the other hand, poultry production from family farming has been recognized as an important subsistence activity in several countries under development, due to its generation of income, particularly for female farmers, by providing inexpensive and high-quality protein-filled foods of animal origin (Moreki 2006). In African, Asian and Latin American continents, $80 \%$ of family farms keep poultry in an extensive system and the animals commonly live together with different species of poultry in the same space (Sonaya \& Swan 2004). In Brazil, this activity is usually nown as caipira, capoeira or backyard poultry, and it is of great importance in certain regions, especially those associated with zootechnical indices of low productivity (Barbosa 2007, Embrapa 2007).

The main factors, that limit the satisfactory performance of this type of activity, are the lack of technical assistance and disease control which, in some cases, can decimate the flock in a short period of time (Moreki 2006). Based on reports from breeders and technical observations, some viral, bacterial and parasitic pathogens may cause diseases (Alders 2005), but there is few studies of the presence of these pathogens. Casagrande et al. (2014) recorded two outbreaks of mycoplasmosis in Rio Grande do Sul caused by Mycoplasma gallisepticum (MG) in backyard poultry. Mycoplasma gallisepticum is the most important species of avian mycoplasma, affecting wild and domestic poultry worldwide and causing great losses in the poultry industry through diseases such as chronic respiratory disease in chickens and infectious sinusitis in turkeys, which can be accompanied by airsacculitis and asymptomatic issues in adult birds (Ley 2003). With regards to family systems of poultry production, there are no data available about the occurrence and impact of this disease in the northeastern Brazil.

The aim of the present study was to determine the occurrence of antibodies anti-Mycoplasma gallisepticum among chickens (Gallus gallus domesticus) and to identify the risk factors associated with Mycoplasma gallisepticum infection on family properties in the semiarid region, state of Pernambuco, Brazil.

\section{MATERIALS AND METHODS}

The samples were collected from 23 small properties that were involved in family production (Brasil 2006) in the cities of Jupi (1), Lajedo (2) and Paranatama (3) in the micro-region of Garanhuns and in Itaíba (4) in the micro-region of Vale do Ipanema in the state of Pernambuco, Brazil, where the climate is predominantly semiarid (IBGE 2011).

Convenience sampling was used in the present study. A total of 300 blood samples were collected in the period of 2011 to 2012 from adult chicken from both sex. The blood samples were obtained by puncturing the brachial vein of adult Gallus gallus domesticus and all of the procedures were assessed and approved by the Ethics Committee for Animal Use (CEUA- Federal University of Alagoas) under protocol number (54/2014).

The ELISA test (IDEXX ${ }^{\circledR}-$ MG, Westbrook, Maine - USA) was used to detect antibodies against MG. The serum samples were diluted in the proportion 1:500 and a cut-off value of 1076 was considered, according to manufacturer's instructions.

In order to compose the sample of the prevalence study, a total of 336,221 chickens were considered (IBGE 2011). The expected prevalence was $30.3 \%$ (Buchala et al. 2006) positive chickens in the study of antibodies anti-Mycoplasma gallisepticum (minimal confidence of $95 \%$ and a statistical error of $6 \%$ ). This parameter provided a minimum sample size of 226 birds to be examined (Thrusfield et al. 2004). Besides, a questionnaire was applied on each property to evaluate the risk factors associated with avian mycoplasmosis.

The variables were assessed through univariate analysis of the variables of interest, using Pearson's chi-squared test or Fischer's. The logistic regression model considered the serological results (positive or negative) as the dependant variable used in the multivariate analysis of the data. Statistical Package for the Social Sciences (SPSS) for Windows version 18.0 was used to perform statistical calculations.

\section{RESULTS}

The ELISA test showed that 157 (52.33\%) of the 300 animals were positive for the presence of antibodies anti-Mycoplasma gallisepticum, with 143 (47.67\%) negative animals. There was, at least, one positive animal $(100 \%$ foci) on each property studied and data related to the number of positive animals per property and city, as well as the minimal and maximal titration of antibodies are summarized in Table 1.

On the 23 properties evaluated or assessed, the animals were mainly bred for consumption $(73.9 \%)$, with the remainder $(26.1 \%)$ bred for poultry and egg commercialization. On 21 of the properties (91.3\%), the poultry were managed by women. Certain general aspects of management were evident on most of the properties, such as the absence of poultry vaccine management $(100 \%)$, the use of alternative therapy for sick animals $(95.6 \%)$ and the indiscriminate use of the same antimicrobial drug for long periods, without the guidance of animal health professionals. Extensive breeding systems were predominant $(100 \%)$ on the properties. The poultry were confined overnight on $82.6 \%$ 
Table 1. Prevalence of birds positive for antibodies antiMycoplasma gallisepticum and intervals between maximal and minimal titers found per property (cut off $\geq 1076$ )

\begin{tabular}{|c|c|c|c|c|}
\hline \multirow[t]{2}{*}{ City } & \multirow[t]{2}{*}{ Property } & \multicolumn{2}{|c|}{ Prevalence } & \multirow{2}{*}{$\frac{\text { Intervals of titers }}{\text { Min.-max. }}$} \\
\hline & & $\mathrm{n}$ & $\%$ & \\
\hline \multirow[t]{4}{*}{1} & 1 & $4 / 15$ & 26.6 & $1192-7927$ \\
\hline & 2 & $7 / 19$ & 36.8 & $1298-5981$ \\
\hline & 3 & $6 / 10$ & 60.0 & $1769-9403$ \\
\hline & 4 & $10 / 11$ & 90.9 & 2774-8134 \\
\hline \multirow[t]{5}{*}{2} & 5 & $8 / 8$ & 100.0 & $1880-7650$ \\
\hline & 6 & $8 / 12$ & 66.6 & $1100-11395$ \\
\hline & 7 & $10 / 11$ & 90.9 & $1769-15846$ \\
\hline & 8 & $6 / 9$ & 66.6 & $1818-17207$ \\
\hline & 9 & $11 / 18$ & 61.1 & $1567-8151$ \\
\hline \multirow[t]{11}{*}{3} & 10 & $17 / 25$ & 68.0 & $1206-10404$ \\
\hline & 11 & $4 / 27$ & 14.8 & $1123-8473$ \\
\hline & 12 & $10 / 10$ & 100.0 & $3368-14532$ \\
\hline & 13 & $6 / 14$ & 42.8 & $1531-5298$ \\
\hline & 14 & $8 / 14$ & 57.1 & $1215-11492$ \\
\hline & 15 & $4 / 13$ & 30.8 & $1135-5943$ \\
\hline & 16 & $5 / 14$ & 35.7 & $1531-5298$ \\
\hline & 17 & $6 / 13$ & 46.1 & $1230-8118$ \\
\hline & 18 & $5 / 13$ & 38.5 & $1222-17431$ \\
\hline & 19 & $4 / 15$ & 27.7 & $1251-8671$ \\
\hline & 20 & $6 / 6$ & 100.0 & $1428-11389$ \\
\hline \multirow[t]{3}{*}{4} & 21 & $1 / 5$ & 20.0 & $1220-1220$ \\
\hline & 22 & $1 / 5$ & 20.0 & $6475-6475$ \\
\hline & 23 & $10 / 13$ & 77.0 & $1423-15030$ \\
\hline Total & 23 & $157 / 300$ & 52.33 & \\
\hline
\end{tabular}

of the properties. Other species of mammals (ruminants, pigs, dogs and cats) and birds (psittacines, passerines, anseriformes, wild birds and/or other chickens) were bred on all $(100 \%)$ of the properties. All of the breeders reported at least one sign of respiratory disease among the poultry. Food and/or water were provided directly on the ground on $100 \%$ of the properties.

A significant association ( $p \leq 0.004)$ was found in the univariate analysis for certain factors, including the periods of crowding and confinement and the presence of rodents (Table 2). The presence of Numida meleagris ( $\mathrm{OR}=2.22$ ); the presence of passerines $(\mathrm{OR}=1.88)$ and the presence of psittacines (OR=1.72) (Table 3) were confirmed by logistic regression and univariate analysis as risk factors for avian mycoplasmosis among backyard poultry.

\section{DISCUSSION}

Family chicken production requires greater attention. Contact between Mycoplasma gallisepticum and domestic chickens has been facilitated in several ways, including systems in which chickens live alongside other domestic poultry species and wild birds (Luttrel et al. 1991, Jessup et al. 1983). It is known that the main sources of infection in the transmission chain of Mycoplasma gallisepticum are sick birds, both reservoirs and carriers (Nascimento 2000). The most relevant transmission routes involve transovarial transmission and direct contact between healthy and sick poultry.

In the present study, the mean frequency of positive birds on the 23 properties studied was $52.33 \%$, ranging from $20 \%$ to $100 \%$. All of the properties exhibited at least one positive bird, with $100 \%$ foci, thereby demonstrating a great dissemination of these bacteria. All of the animals assessed were positive on three of the properties studied $(5,12$ and 20$)$. These results are higher than the mean value reported by Buchala et al. (2006), who found an overall relative frequency of $30.3 \%(123 / 406)$ in the state of São Paulo, with $73 \%$ foci (11/15). In Zimbabwe, Kelly et al. (1994) collected data about the health and management of backyard chickens in an urban commercial poultry area and found that $33 \%$ of the commercialized chickens exhibited antibodies anti-Mycoplasma gallisepticum or Mycoplasma sinoviae.

Studies addressing antibodies anti- Mycoplasma gallisepticum in family-reared poultry are scarce on a worldwi-

Table 2. Univariate analysis of the risk factors associated with Mycoplasma gallisepticum infection among chickens in the state of Pernambuco, Brazil

\begin{tabular}{lllll}
\hline Variables & \multicolumn{3}{c}{ Frequency } & Values \\
\cline { 2 - 4 } & FA & FR\% & OR $^{\text {a }}$ & P-value \\
\hline
\end{tabular}

Breeding of Numida meleagris

(guinea) on the property

Yes

No

$\begin{array}{cccc}70 & 47 & 2,22 & 0,003^{*} \\ & (67.1 \%) & (1,23-4,10) & \\ 230 & 110 & & \\ & (47.8 \%) & \end{array}$

Breeding of passerines

on the property

Yes

177

$\begin{array}{cc}104 & 1,88 \\ (58.8 \%) & (1,15-3,08) \\ 53 & \end{array}$

No

$123 \quad(43.1 \%)$

Breeding of psittaciformes

(parakeets, parrots)

on the property

Yes

103

63

$1,72 \quad 0,017^{*}$

No

$197 \quad 94$

94

Presence of rodents in the breeding area of the poultry? Yes

$\begin{array}{cccc}254 & 127 & 0,53 & 0,040 * \\ & (50.0 \%) & (0,25-1,06) & \\ 46 & 30 & & \\ & (65.2 \%) & \end{array}$

Periods of confinement/ crowding for the poultry? Yes

$206 \begin{array}{ccc}97 & 0,50 & 0,004 * \\ & (47.1 \%) & (0,29-0,85) \\ & 60 & \\ & (63.8 \%) & \end{array}$

${ }^{\mathrm{a}} \mathrm{OR}=$ Odds ratio, ${ }^{*}$ Significant association at $5 \%$.

Table 3. Logistic regression (multivariate analysis) of the risk factors associated with Mycoplasma gallisepticum infection among chickens in the state of Pernambuco, Brazil

\begin{tabular}{|c|c|c|c|}
\hline Variables & p-value & $\mathrm{OR}^{\mathrm{a}}$ & CI 95\% ${ }^{\mathrm{b}}$ \\
\hline $\begin{array}{l}\text { Presence of Numida meleagris } \\
\text { on the property (Yes/No). }\end{array}$ & 0,005 & 2,22 & $1,27-3,90$ \\
\hline $\begin{array}{l}\text { Presence of passerines on } \\
\text { the property (Yes/No). }\end{array}$ & 0,007 & 1,88 & $1,18-2,99$ \\
\hline $\begin{array}{l}\text { Presence of psittaciformes (parakeets, } \\
\text { parrots) on the property (Yes/No). }\end{array}$ & 0,027 & 1,72 & \\
\hline
\end{tabular}

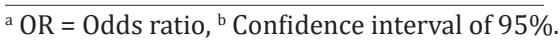


de scale. In Argentina, Xavier et al. (2011) studied family properties in the rural zone of the city of Entre Rios and reported a high prevalence of avian mycoplasmosis (Mycoplasma gallisepticum and Mycoplasma. sinoviae), based on analysis of three periods from 2003 to 2007 . The mean prevalence rates found were $32.8 \%, 55.1 \%$ and $76.2 \%$ respectively. In the present study, certain locations recorded a frequency of $100 \%$, with prevalence rates ranging from $21.7 \%$ to $100 \%$.

It is known that ELISA detects IgG class antibodies 7-10 days after infection and these antibodies remain in the bird for up to 80 days (Bradbury \& Morrow 2008). The test kit used in the present study enabled an assessment of the serologic profile of each animal and confirmed an elevated percentage of antibody titers against Mycoplasma gallisepticum, ranging from 1,100 to 17,431 (cut-off=1.076). In the routine of the poultry industry, the highest titers reach the titration group that rarely exceeds 4,000 , compatible with the vaccine reaction for live attenuated strains and/or the passive transmission of immunity. In the present study, the titers attained intervals that varied from slightly above the cut-off (1.076) to approximately 13 times this value (17.431). This demonstrates the challenge to be faced in the field, given that the poultry in the present study were never vaccinated. The course of the infection was also different among the animals studied and this was confirmed by the presence of clinical respiratory signs, associated with mycoplasmosis, among birds that were infected and others that were apparently healthy.

The presence of passerines on the properties studied was identified as a risk factor for Mycoplasma gallisepticum dissemination among chickens (OR=1.88, $\mathrm{p}=0.007)$. This finding is of great importance since in this region, certain species of passerines are reared in cages like household animals, or in large numbers for commercial reasons. One example of this activity is the breeding of Serinus canaria which can be a significant source of Mycoplasma gallisepticum infection. The northeastern goldfinch (Carduelis yarrellii) is another fringillidae passerine that occurs naturally in this region.

Vitula et al. (2011) reported deaths provoked by respiratory problems caused by Mycoplasma gallisepticum in Perdix perdix, a bird from the same family as the domestic chicken and turkey. Poveda et al. (1990) found Mycoplasma gallisepticum in samples of respiratory tract and tissues from quails (Coturnix coturnix) and peregrine falcons (Falco peregrinus). Benčina et al. (1987) also demonstrated the occurrence of infection among turkeys, pigeons, quails and chickens, showing the importance of free-living wild or domestic poultry in the transmission of M. gallisepticum. In the present study, one of the risk factors associated with M. gallisepticum infection in domestic chickens was the presence of Angolan chickens (Numida meleagris) (OR=2.22; $\mathrm{p}=0.005)$. Reports identifying Mycoplasma gallisepticum directly or indirectly in Angolan chickens are scarce. However, it cannot be ignored that this species could be a host of this agent. Pascucci et al. (1976) reported natural sinovitis by Mycoplasma synoviae in Numida meleagris in Italy and there are rese- archers who consider its occurrence to be common in this poultry species (Friend \& Franson 1999).

The logistic regression also indicated the presence of psittacines (OR=1.72; $\mathrm{p}=0.027$ ) on the properties as a risk factor for Mycoplasma gallisepticum infection in chickens. In general, among the psittacine species that occur naturally in the semiarid Northeast of Brazil, the most commonly found captive animals are true parrots (Amazona aesti$v a$ ), caatinga parakeets (Aratinga cactorum) and Australian parakeets (Melopsittacus undulatus). The latter is an exotic, although widespread, species on domestic farms in Brazil. This risk factor should be studied further in the region, given that there are reports associating Mycoplasma gallisepticum and Mycoplasma sinoviae with Amazona auropalliata, a parrot that is native to Central America, after an outbreak of respiratory disease and death. These isolates have been used to infect parakeets experimentally (Melopsittacus undulatus) and the animals subsequently developed airsacculitis. Mycoplasma gallisepticum was reisolated and promoted seroconversion in white Leghorn chickens, which produced antibodies anti- Mycoplasma gallisepticum, measured by the agglutination test (Bozeman et al. 1984). Gomes et al. (2010) detected a high incidence of Mycoplasma gallisepticum using the polymerase chain reaction (PCR) and 140 biological samples, which were collected by cloacal swabs from the tracheas and cleft palates of seven species of wild Brazilian psittacines that died from respiratory complications.

Although there was no statistical association between the presence of turkeys (Meleagridis gallopavo) and mycoplasmosis in chickens in the present study, $52.2 \%(12 / 23)$ of the properties contained at least one turkey. In addition, clinical respiratory problems were observed in this species on three of the properties, characterized by different degrees of sinusitis, an increase in the unilateral infraorbital volume, moderate conjunctivitis and catarrhal exudate in the nostrils and tear ducts. These findings are commonly associated with sinusitis in turkeys caused by Mycoplasma gallisepticum (Ley 1996). In California, Jessup et al. (1983) confirmed the occurrence of sinusitis in turkeys that lived together with asymptomatic chickens. The same authors were able to isolate Mycoplasma gallisepticum, which caused airsacculitis in susceptible chickens after a bioassay. Stressful conditions, such as agglomerations and contact between species, have previously been reported by numerous authors as factors that predispose the occurrence of mycoplasmosis in different poultry species (Ley 1996, Luttrell et al. 2001, Gomes et al. 2010). In the present study, the agglomeration and confinement of poultry was a risk factor for Mycoplasma gallisepticum infection in the univariate analysis. Although the statistical analysis indicated respiratory illnesses as a positive association with $\mathrm{Myco-}$ plasma gallisepticum infection, it is known that these problems can be caused by other infections agents, including viruses, fungi and bacteria.

The epidemiological findings pioneered in the present study should stimulate further studies that take into consideration the growing demand for more naturally produced products, the generation of income for female farmers and 
the health implications that this type of activity could have on the poultry industry in the region, if the lack of official health policies continues. Studies should also be conducted to enable a genetic characterization of the strain found in the region studied.

\section{CONCLUSIONS}

The results of the present study enable us to conclude that Mycoplasma gallisepticum infection is endemic among family-reared chickens in the semiarid region of the state of Pernambuco.

These birds could be a source of infection for other wild and domestic poultry and the risk factors identified in the present study should serve as a parameter for health authorities to seek solutions to control the disease.

Acknowledgements.- The authors would like to thank the Fundação de Amparo à Ciência e Tecnologia (FACEPE) for financial support.

\section{REFERENCES}

Alders R. 2005. Produccíón Avícola por Benefício y por Placer. Folleto de la FAO sobre diversificación 3. Dirección de Sistemas de Apoyo a la Agricultura, Food and Agriculture Organization of the United Nations, Rome. ISBN 9253050756.

Barbosa F.J.V., Nascimento M.P.S.B., Diniz F.M., Nascimento H.T.S. \& Araújo Neto R.B. 2007. Sistema alternativo de criação de galinhas caipiras. Embrapa Meio-Norte, Teresina. 68p. ISSN 1678-0256. <http://ainfo.cnptia.embrapa.br/digital/bitstream/item/80710/1/sistemaproducao-4. PDF> Accessed Sept. 2014.

Benčina D., Dorrer D. \& Tadina T. 1987. Mycoplasma species isolated from six avian species. Avian Pathol. 16:653-664.

Bozeman L.H., Kleven S.H. \& Davis R.B. 1984. Mycoplasma challenge studies in budgerigars (Melopsittacus undulatus) and chickens. Avian Dis. 28:426-434.

Bradbury J.M. \& Morrow C.J. 2008. Avian mycoplasmas, p.220-234. In: Pattison M., McMullin P.F., Bradbury J.M. \& Alexander D.J. (Eds), Poultry Diseases. Saunders Elsevier, Philadelphia.

Brasil 2006. Lei 11.326/2006 (lei ordinária). Diário Oficial da República Federativa do Brasil, Brasília, DF, 24 Jul. 2006.

Buchala F.G., Ishizuka M.M., Mathias L.A., Berchieri Júnior A., Castro A.G.M., Cardoso A.L.S.P., Tessari E.N.C. \& Kanashiro A.M.I. 2006. Detecção de resposta sorológica contra Mycoplasma em aves de criatórios de "fundo de quintal" próximos a explorações comerciais do estado de São Paulo. Arqs Inst. Biológico, São Paulo, 73:143-148.

Casagrande R.A., Castro L.A., Rolim V.M., Wouters F., Boabaid F.M., Souza S.O., Guerra P.R., Silva S.C. \& Driemeier D. 2014. Diagnóstico imunohistoquimico e caracterização anatopatologica da Mycoplasma gallisepticum em galinhas de subsistência. Pesq. Vet. Bras. 34:153-161.

Embrapa 2007. Criação de Galinhas Caipiras: ABC da Agricultura Familiar 20. Brasília, DF. < http://ainfo.cnptia.embrapa.br/ digital/bitstream/ item/42033/1/ Cartilha-00081600.pdf> Accessed Aug. 2014.

Friend M. \& Franson J.C. 1999. Mycoplasmosis, p.115-118. In: Ibid. (Eds), Field Manual of Wildlife Diseases: general field procedures and disease of birds. U.S. Geological Survey, Biological Resources Division Information and Technology Report 1999-2001, Reston, Virginia. <http://www.nwhc.usgs.gov/ publications/field_manual/field_manual_of_wildlife_diseases.pdf>
Gomes A.M., Costa L.L., Vilela D.A.R., Marques M.V.R., Carvalhaes A.G., Marin S.Y., Costa M.P., Horta R.S., Resende J.S. \& Martins N.R.S. 2010. Detection of Mycoplasma gallisepticum in dead captive psittacines in Belo Horizonte, Brazil. Braz. J. Poult. Sci. 12:75-78.

IBGE. Instituto Brasileiro de Geografia e Estatística. 2011. <ftp://geoftp. ibge.gov.br/organizacao_territorial/ semi_arido/semi_arido_brasileiro.pdf> Accessed Oct. 2013.

Jessup D.A., DaMassa A.J., Lewis R. \& Jones K.R. 1983. Mycoplasma gallisepticum infection in wild-type turkeys living in close contact with domestic fowl. Am. Vet. Med. Assoc. 183:1245-1247.

Kelly P.J., Chitauro D., Rohde C., Rukwava J., Majok A., Davelaar F. \& Mason P.R. 1994. Diseases and management of backyard chicken flocks in Chitungwiza, Zimbabwe. Avian Dis. 38:626-629.

Ley D.H. 1996. Mycoplasma gallisepticum infection, p.722-744. In: Saif Y.M., Barnes H.J., Glisson J.R., Fadly A.M., McDougald L.R. \& Swayne D.E., (Eds), Diseases of Poultry. Iowa State University Press, Ames.

Ley D.H. 2003. Mycoplasma gallisepticum infection, p.122-144. In: Saif Y.M., Barnes H.J., Fadly A.M., Glisson J.R., McDougald L.R. \& Swayne D.E. (Eds), Diseases of Poultry. 11th ed. Iowa State University Press, Ames.

Luttrell M.P., Kleven S.H. \& Davidson W.R. 1991. An investigation of the persistence of Mycoplasma gallisepticum in an eastern population of wild turkeys. J. Wildl. Dis. 27:74-80.

Luttrell M.P., Stallknecht D.E., Kleven S.H., Kavanaugh D.M., Corn J.L. \& Fischer J.R. 2001. Mycoplasma gallisepticum in house finches (Carpodacus mexicanus) and other wild birds associated with poultry production facilities. Avian Dis. 45:321-329.

Moreki J.C. 2006. Family poultry production. Poultry Today, Poultry Section, Animal Production Division, Department of Animal Production, Gaborone, Botswana. <http://www.gov.bw/PageFiles/4502/ Acrobat $\% 20$ Document.pdf $>$ Accessed Sept. 2014.

Nascimento E.R. 2000. Micoplasmoses, p.217-224. In: Berchieri Júnior R.A. \& Macari M. (Eds), Doenças das Aves. FACTA, Campinas.

Pascucci S., Maestrini N., Govoni S. \& Prati A. 1976. Mycoplasma synoviae in the guinea-fowl. Avian Pathol. 5:291-297.

Poveda J.B., Carranza J., Miranda A., Garrido A., Hermoso M., Fernandez A. \& Domenech J.1990. An epizootiological study of avian mycoplasmas in southern Spain. Avian Pathol. 19:627-633.

Sonaya E.B. \& Swan S.E.J. 2004. Animal Production and Health: manual. Small-Scale Poultry Production: technical guide. Food and Agriculture Organization of the United Nations, Rome. ISSN 1810-1119.

Thrusfield M.V. 2004. Epidemiologia Veterinária. 2ª ed. Roca, São Paulo.

Turra F. 2012. Unshakable Commitment to Sustainability, n.1. Brazilian Poultry Association - UBABE, São Paulo, 32p. Accessed Aug. 2014. <http://www.ubabef.com.br/files/publicacoes/c6f5288fa2288d597adb60b8754b9f8fpdf>

Vitula F., Peckova L., Bandouchova H., Pohanka M., Novotny L., Jira D., Kral J., Ondracek K., Osickova J., Zendulkova D., Rosenbergova K., Treml F. \& Pikula J. 2011. Mycoplasma gallisepticum infection in the grey partridge Perdix perdix: outbreak description, histopathology, biochemistry and antioxidant parameters. BMC Veterinary Research. doi: 10.1186/1746-6148-7-34

Xavier J., Pascal D., Crespo E., Schellt H.L., Trinidad J.A. \& Bueno D.J. 2011. Seroprevalence of Salmonella and Mycoplasma infection in backyard chickens in the state of Entre Ríos in Argentina. Poult. Sci. 90:746-775.

UBABEF. União Brasileira de Avicultura. 2014. Relatório anual. Disponível em: <http://www.ubabef.com.br/files/publicacoes/8ca705e70f0cb11 0ae3aed67d29c8842.pdf>. Acesso em: 10 de fev. 2015. 